\title{
ŠPECIFIKÁ SERIÁLOVÝCH ADAPTÁCIÍ ROMÁNU ${ }^{1}$
}

\section{Specifics of Serial Adaptation of the Novel}

Keywords: serial adaptation, classic novel adaptations, serie, novel, Anna Karenina

Contact: Univerzita Pavla Jozefa Šafárika v Košiciach; gabi.homolova@gmail.com

Literatúra zohrala dôležitú úlohu nielen pri zrode kinematografie, ale aj televízie. Adaptácie literárnych diel sa podiel'ali na formovaní televízneho vysielania, v ktorom sa ako jeden zo základných televíznych programov udomácnil aj seriál, ktorý bol bud’ pôvodný, napísaný priamo pre televíziu, alebo podobne ako film čerpal námety $\mathrm{z}$ literatúry. $\mathrm{V}$ druhom prípade seriál predstavuje osobitý priestor najmä pre adaptovanie rozsiahlejšej literárnej predlohy, akou je napríklad románové dielo, ked’že v porovnaní s filmom sú časové možnosti seriálu na prvý pohl’ad neobmedzené.

Seriál ako ,viacčast'ové dielo vytvárajúce uzavretý celok, zverejňované alebo vysielané v istých časových intervaloch“ (Mrlian 1990: 308) nie je novinkou, ktorá sa objavila so vznikom televízie. Jeho predchodcov nájdeme napríklad v románoch na pokračovanie uverejňovaných v novinách $\mathrm{v} 2$. polovici 18. storočia, ale aj v starovekej či stredovekej epike (prednes dlhého eposu po častiach). Po rozšírení televízie do domácností po 2. svetovej vojne sa seriál stal jedným z dominantných naratívnych žánrov televíznej masmediálnej produkcie. Postupne sa prispôsobil aj jeho vysielací čas a periodicita: ,popri každodenných (či obdenných) soap operách sa objavujú aj seriály s týždennou periodicitou a ich hlavný vysielací čas sa presúva do najsledovanejších častí dňa, tzv. prime-timu, teda do podvečerných a večerných hodín.“ (Rusnák 2010: 223). Napriek tomu, že staršia literatúra za seriál považuje „dielo pozostávajúce najmenej zo šiestich častí (ostatné sú ako troj, štvor, či pät’dielne inscenácie, hry alebo filmy“ (Mrlian 1990: 380), uprednostňujeme terminológiu, ktorú používa Kokeš, ktorý ho definuje ako „fikční audiovizuální dílo složené z více než dvou epizod (seriálových dílů), které mají

\footnotetext{
${ }^{1}$ Príspevok je súčast'ou riešenia grantového projektu APVV-19-0244 Metodologické postupy v literárnovednom výskume s presahom do mediálneho prostredia. Zodpovedný riešitel’: prof. PhDr. Ján Gbúr, CSc. Doba riešenia: 2020-2024.
} 
společné znaky a tvoří makrostrukturu seriálu - a to nezávisle na tom, jestli epizody na sebe navazují nebo sa vzájemně variují.“" (Kokeš 2011: 228).

Je dôležité spomenút', že seriál v súčasnosti už nie je iba výsadou televízneho vysielania. V posledných rokoch sa začínajú stierat' hranice medzi televíznou a filmovou produkciou a pri sledovaní seriálu niekedy nadobúdame pocit sledovania viacdielneho filmu. Vznikajú rôzne streamovacie platformy ako Netflix, Amazon Prime, HBO GO a pod., ktoré bud' prinášajú podobne ako televízia v pravidelnom čase novú epizódu, alebo vydávajú všetky epizódy celej série naraz. Staré princípy uvažovania o seriáloch preto nemôžeme v súčasnosti považovat' za stopercentne platné. Zmenili sa totiž nielen technologické možnosti, ale aj vkus mediálneho publika. Vplyv spoločenských trendov sa odráža najmä na tvorbe mediálnych produktov určených pre široké publikum, a teda ho môžeme pozorovat' aj v súčasných seriáloch, medzi ktorými majú špecifické miesto aj seriálové adaptácie.

Pod termínom seriálová adaptácia máme na mysli audiovizuálne dielo seriálového typu, ktoré vzniklo na základe literárnej predlohy, pričom informácia, že ide o adaptáciu, nemusí byt divákovi explicitne podaná vo forme úvodných titulkov. Najmä tvorcovia súčasných seriálových adaptácií nie vždy upozorňujú na vzt’ah s iným dielom a v prípade úspechu prvej série vytvárajú série, ktoré s prototextom už zvyčajne nesúvisia, prípadne z neho preberajú iba niektoré prvky, napríklad postavy. Opačne je to pri tzv. klasických románových adaptáciách, pri ktorých sa podl’a Zatloukalovej (2011) najzretel'nejšie prejavujú špecifické znaky seriálových adaptácí́. Ide o označenie seriálových adaptácií klasických románov 19. a začiatku 20. storočia. Informácia, že ide o adaptáciu, je v prípade klasických románových adaptácií priznaná hned’ na začiatku v úvodných titulkoch a počas celého trvania diela môže divák pozorovat' výraznú spätost' s literárnou predlohou. Pri tomto type seriálových adaptácií zostáva dôležitý verbálny aspekt diela, pričom dialógy postáv sú často prevzaté s minimálnymi zmenami. Dôraz je kladený na postupné vykreslenie vzt'ahov medzi postavami. (Cardwell 2007) Vzhl'adom na kultúrny a technologický vývoj sa postupne upúšt’a od snahy dodržat' čo najväčšiu vernost' voči predlohe, avšak aj nad’alej si tento typ adaptácií zachováva svoju žánrovú identitu, a to aj napriek tomu, že: „nově vznikající adaptace vycházejí poměrně radikálními změnami ve formátu a stylu seriálu vstř́c požadavkům publika ovlivněného ostatními televizními žánry i filmovou tvorbou.“ (Zatloukalová 2011: 221).

So seriálom úzko súvisí aj termín séria, ktorá má podobné črty, a taktiež sa používa na označenie viacdielneho textu. Na rozdiel od seriálu jej jednotlivé časti vytvárajú autonómny celok, pričom každú čast' možno uvádzat’ aj samostatne. Častým dôvodom pre vznik série je úspech diela, ktoré sa stalo inšpiráciou na vytvorenie pokračovania (Mrlian 1990: 380). Pod termínom séria však môžeme chápat’ aj seriálový 
rad, teda súbor viacerých epizód vytvárajúcich uzavretý celok, ktorý môže, ale nemusí navodzovat' potrebu pokračovania deja. Aj v tomto prípade vznik d’alšej série (seriálového radu) často súvisí s ekonomickou situáciou, sledovanost'ou a úspechom u publika. Ďalším seriálovým typom, ktorý sa teší obl’ube divákov, je miniséria. Miniséria predstavuje naratívnu formu, ktorú môžeme prirovnat' k viacdielneho filmu. Jednotlivé časti na seba priamo nadväzujú a nasledujúca epizóda pokračuje tam, kde predchádzajúca skončila. V epizódach sa nezvyknú prezentovat' samostatné príbehy, ale dejová línia prekračuje hranice jednotlivých epizód. Pre potreby tohto príspevku budeme seriálovými adaptáciami označovat' viacdielne audiovizuálne diela ako seriál, tak aj minisériu, ktoré vznikli na základe literárnej predlohy.

\section{K adaptáciám románu Anna Kareninová}

Lev Nikolajevič Tolstoj je známy predovšetkým ako tvorca vel'kých epických foriem, a ked’že sa seriál svojím charakterom približuje rozmernej epickej próze, vybrali sme si na analýzu práve jeden z románov tohto autora. Anna Kareninová patrí medzi diela, ktorých počet adaptácií (filmových, seriálových, divadelných a pod.) sa pohybuje $\mathrm{v}$ desiatkach. Vychádzajúc $\mathrm{z}$ terminológie Aujezdského (2006), ktorý adaptácie rozdel'uje na základe vzt’ahu k predlohe na 3 typy: adaptácie verné predlohe, adaptácie s tvorivým vkladom scenáristu a adaptácie na motívy, by sme mohli väčšinu filmových adaptácií románu Anna Kareninová označit’ ako adaptácie verné predlohe, v ktorých je však najväčší priestor venovaný dejovej línii súvisiacej s Annou. Druhá dominantná línia opisujúca život Levina je zvyčajne zobrazená iba niekol'kými scénami, ktoré by sme v prototexte mohli označit' za tzv. jadrové udalosti príbehu. Aby sme podl'a Pašteku správne pochopili tento román musíme ho chápat' „, celej zložitosti tematickopersonálnej výstavby, ako kompozične jednotný útvar $\mathrm{s}$ niekol'kými tematickosujetovými plánmi. Tieto plány nie sú od seba oddelené, naopak, navzájom mnohonásobne pospájané, mnohostranne poprepletané.“ (Pašteka 2005: 136). Pre súčasného čitatel'a sa však niektoré pasáže súvisiace s Levinom opisujúce najmä jeho filozofovanie nad životom, hospodárske projekty, pol'ovačky či vol'by môžu zdat' retardačné a nezaujímavé, preto sú vo väčšine adaptácií tieto scény oklieštené alebo úplne eliminované.

V príspevku sa detailnejšie zameriame na štyri seriálové adaptácie tohto románu, všetky s rovnomenným názvom Anna Kareninová. Zhodnotíme, či rovnako ako pri filmových adaptáciách, sa snažili tvorcovia o čo najvernejšie dodržanie predlohy a či sa im podarilo preniest' dielo na obrazovky bez výraznejších zásahov do pôvodného príbehu, zároveň si budeme všímat', do akej miery využili režiséri výhody seriálového 
spracovania vzhl’adom na priblíženie druhej dominantnej línie súvisiacej s Levinom, a ked’že v prototexte Anna umiera v závere 7. časti románu a román pokračuje bez nej 8. čast'ou, vktorej čitatel' nachádza ideové vyústenie diela skrz postavu Levina, pozornost' upriamime taktiež na záverečné scény seriálových spracovaní.

\section{Anna Kareninová, 1977, réžia: Basil Coleman}

10-dielne britské seriálové spracovanie románu z roku 1997, ktorého režisérom bol Basil Coleman, môžeme označit ako klasickú románovú adaptáciu vd’aka svojím špecifickým znakom: informácia, že ide o adaptáciu je uvedená už v úvodných titulkoch a pozornejšiemu divákovi neujdú takmer identické dialógy s prototextom. Vzhl'adom na obdobie, v ktorom táto seriálová adaptácia vznikla sú pre ňu príznačné dlhé zábery súvisiace aj s technologickými možnosti a strihová skladba charakteristická pre vtedajšiu seriálovú tvorbu (Giddings 2001). Jednotlivé epizódy síce na seba priamo nadväzujú, avšak v ich závere nemôžeme hovorit' o akomsi dramatickom napätí, ktoré by malo navodit' $\mathrm{v}$ divákovi potrebu pokračovania, tzv. cliff-hanger „označujúci záverečné anotácie, ktoré tvorcovia umiestňujú na záver častí televízneho seriálu s ciel’om poistit' záujem diváka o d’alšiu čast' televízneho seriálu, prípadne série.“ (Rusnák 2010: 22). V porovnaní s filmovými adaptáciami je $\mathrm{v}$ tomto seriálovom spracovaní daný väčší priestor postave Levina, iba v 4. časti sa neobjaví ani raz, inak sa scény zobrazujúce líniu Anny a Levina navzájom striedajú. Zaujímavé je, že v porovnaní s prototextom, je Levinova línia uzavretá skôr ako Annina. V závere vidíme, ako sa Kitty narodí diet’a a Levin sa teší zo svojej rodiny a až po tejto scéne je zobrazená Anna prichádzajúca na železničnú stanicu. Divák má však pocit, že dej negraduje ani pár minút pred koncom. Posledné scény zobrazujú Annu, ktorá sa hádže pod vlak a neskôr Vronského, ktorý drží jej kabelku v rukách a seriál končí, ked' sa Vronskij pozrie smerom hore smerom $\mathrm{k}$ oblohe. Po tomto zábere nasledujú záverečné titulky. Celý seriál teda rámcuje príbeh Anny, ktorým sa začína aj prvá čast' (vidíme vlak počas snehovej víchrice). Pri tomto type ide o čo najdôveryhodnejšie spracovanie klasického románu, preto sa tempo celého seriálu môže dnešnému divákovi, ktorý je zvyknutý na rýchly strih, zdat' pomalé až retardačné.

\section{Anna Kareninová, 2000, réžia: David Blair}

4-dielna miniséria z Vel'kej Británie prináša už v úvode pohl’ad na cvičiaceho nahého Levina a v celom spracovaní sa neskôr objaví niekol'ko explicitnejšie zobrazených sexuálnych scén. Podobne ako v predchádzajúcej seriálovej adaptácii, aj tu je priznaná informácia, že ide o adaptáciu Tolstého diela už v úvodných titulkoch a odhliadnuc od 
nevyhnutnej kompresie románovej predlohy, adaptáciu by sme mohli označit' ako vernú predlohe. Oproti predchádzajúcej však pozorujeme ,modernejšie tendencie“ či už čo sa týka rýchlejšieho strihu alebo práce s kamerou. Aj závery jednotlivých častí končia v dramatickom momente, ked' divák nevie, čo bude nasledovat'. Napríklad v závere prvej časti sa Anna prizná manželovi Kareninovi, že je Vronského milenka, v závere druhej časti sa Vronský pokúsi zastrelit’, divák, ktorý nepozná predlohu, nevie, či sa mu to podarí, alebo nie, v závere tretej časti si Anna uvedomí, aký život vedie a obviňuje Vronského, že sa vzdala syna kvôli nemu, v závere štvrtej časti síce Anna zomiera, ale touto scénou nekončí celá miniséria. Príbeh pokračuje d’alšími zábermi po určitej dobe - Stiva a Doly sa objímajú, Levin sa rozpráva s Vronským o Anne, ale i jeho dcére a v úplne poslednom zábere vidíme spokojnú Levinovu rodinu, Kitty a syna, ktorí sa pozerajú na dlho očakávaný dážd', ktorý nielenže vyrieši problém sucha, ale môžeme ho chápat' aj symbolicky, zmyje všetky ich životné problémy. Celý príbeh tejto série je teda rámcovaný líniou Levina.

\section{Anna Kareninová, 2009, réžia: Jurij Klimenko}

Tvorcovia 5-dielnej ruskej minisérie si dali záležat' na detailnom vykreslení ruského prostredia od začiatku do konca. V jedinej spomedzi nami analyzovaných seriálových adaptácií je už od prvej scény opisujúcej situáciu u Oblonských prítomný rozprávač, ktorý nielen posúva dej, ale taktiež komentuje dianie a približuje vnútorný svet postáv, aby divák náhodou nepochopil Tolstého dielo nesprávne. Každá epizóda má svoj vlastný názov (1. Metelica, 2. Dôstojnícke preteky, 3. Svadba, 4. Ona nie som ja, 5. Ja odplatím), ktorý divákovi, ktorý pozná predlohu, naznačí ich obsah. Iba jedna z častí je pomenovaná podl'a Levinovej línie - svadba, a to aj napriek tomu, že jeho línia je v porovnaní s Anninou v celom seriáli rovnomerne zastúpená. Podobne ako v adaptácii z 1977 - miniséria končí najprv uzatvorením Levinovej línie. Levin počas búrky hl'adá Kitty so synom a ked' ich nájde, jeho strach sa mení na radost' z rodiny. Aj Anninu líniu uzatvára búrka. Anna ukončí svoj život pod kolesami vlaku a následne na stanicu prichádza Vronskij. Nasleduje dlhý záber na mŕtvolu a ked' odkryje Anninu tvár, v tom momente vidíme blesk a začína búrka. Aj v tomto prípade si môžeme tento dážd' vysvetlit' tak, že má zmyt' a odplavit' všetko zlé, čo sa stalo. Posledný záber je vel'mi špecifický, žiadna zo seriálových (ani filmových) adaptácií nekončí podobne. Vidíme manžela Anny - Karenina, ktorý drží na rukách Anninu dcéru a spoločne cez okno pozerajú na Seriožu, ako sa korčul'uje. Ten v istom momente na l'ade spadne, avšak po chvíli sa postaví a korčul'uje d'alej. Môžeme si to vysvetlit' aj tak, že tvorcovia tejto adaptácie sa v závere rozhodli poukázat' na deti, ktoré zostali bez matky. Aj ked’ Anna 
chcela svojou smrt'ou potrestat' Vronského, najviac trpia jej deti, ich život však nekončí, možno sa na chvíl'u zastavil, ale musia vstat' a pokračovat' d'alej.

\section{Anna Kareninová, 2017, réžia: Karen Šachnazarov}

Fakt, že sa Tolstému podarilo vytvorit’ a spojit' dva životné príbehy, ktoré sú síce prepojené, ale môžu vystupovat' aj samostatne, potvrdzuje aj najnovšie seriálové spracovanie tohto románu, kde pozorujeme úplné eliminovanie postavy Levina. Vzt'ah Levina a Kitty v tomto prípade nie je vykreslený vôbec a Kitty vidíme v celom diele iba raz na úvodnom plese a o jej živote sa neskôr dozvedáme iba z rozprávania Dolly. Predlohou tejto adaptácie však nebol len Tolstého román, ale aj román ruského autora Vinkentija Veresajeva Zápisky z Japonskej vojny, o ktorých sa dozvedáme hned' z úvodných titulkov. Z hl'adiska vernosti by sme túto adaptáciu neoznačili ako adaptáciu vernú predlohe, ale ako adaptáciu s tvorivým vkladom scenáristu. Rozprávačom príbehu je Vronskij a na priblíženie Anninej línie je využitá retrospektíva. Svoju históriu rozpovedá 30 rokov po Anninej smrti jej synovi Sergejovi, ktorý je velitel’om vojenskej nemocnice počas rusko-japonskej vojny. Tento 8-dielny seriál existuje aj v skrátenej kinoverzii s názvom Anna Kareninová. Príbeh Vronského.

\section{Záver}

Aj ked' seriál podl'a Kokeša (2011) predstavuje amébovú naratívnu formu, ktorá sa môže rozvíjat' a menit' donekonečna vytváraním stále d'alších seriálových radov, v prípade seriálovej adaptácie môže byt' táto naratívna forma kvôli korelácii s literárnou predlohou obmedzená, najmä ked’ ide o adaptáciu diela ako je román Anna Kareninová, ktorého dej je definitívne ukončený smrt'ou hlavnej postavy. Analyzované adaptácie môžeme označit' ako verné predlohe, no zároveň v najnovšom seriálovom spracovaní vidíme tendenciu posunút' príbeh za hranicu prototextu. V porovnaní s filmovými spracovaniami tohto románu, síce tvorcovia detailnejšie zobrazili Levinovu líniu, ale väčšinou len v prípade, ked' touto postavou rámcovali príbeh, avšak smerom k rozvíjaniu vedl'ajších línií z prototextu sa neuberali. Naopak poslednú adaptáciu Tolstého románu doplnili o iný príbeh a úplne eliminovali líniu s Levinom. Všeobecne platí, že ,šírka románovej plochy núti dramaturgiu selektovat' jednotlivé motívy románového príbehu, naopak poviedkový útvar umožňuje dramaturgii rozvádzat' jednotlivé motívy literárneho prototextu“ (Sabol 2021: 9), ale v najnovšom seriálovom spracovaní môžeme vidiet' doplnenie dejových línií (aj z iných textov), ktoré sa môžu javit' pre súčasného diváka lákavejšie ako tie, o ktorých píše autor v prototexte. A tak si v závere kladieme otázku, či by bolo možné preniest' Annin príbeh do viac než desiatich 
častí, prípadne niekol'kých sérií, aj v prípade, že tragický osud Anny zostane nezmenený.

\section{Summary}

The influence of social trends affects also on serial production, where we can difference between serial adaptations and original series. Modern serial adaptations do not used to refer to prototext, but the second type - classic novel adaptations always point to a relationship with a literary text. The paper focuses on four classic serial adaptations of the novel by L. N. Tolstoy - Anna Kareninová. Although they adhere to the relationship to the original, in the latest serial processing we observe the tendency of the creators to move the story beyond the limits of the prototext.

\section{Literatúra}

Aujezdský, P. Od knížky k televíznímu filmu. Brno: Janáčkova akademie múzických umění v Brně, 2009.

Cardwell, S. Literature on the small screen: television adaptations. 2007. Dostupné z: /https://www.academia.edu/657528/Literature_on_the_small_screen_television _adaptations/ (2021-03-15).

Giddings, R. The Classic Serial on Television and Radio. New York: Palgrave Macmillan, 2001.

Kokeš, R. Teorie seriálové fikce. Možné cesty naratologické analýzy televízního seriálu. In: Fedrová, S., Jedličková, A. (eds.) Intermediální poetika přiběhu. Praha: Akropolis, 2011, s. 228-257.

Mrlian, R. Encyklopédia dramatických umení Slovenska. Bratislava: VEDA, 1989.

Pašteka, J. Svet literatúry, literatúra sveta. Analýzy a interpretácie II. zväzok. Bratislava: Petrus Publishers, 2005.

Rusnák, J. et al. Texty elektronických médií: Stručný výkladový slovník. Prešov: Prešovská univerzita v Prešove, 2010.

Sabol, J. S. Interpretácia filmového diela. Košice: Univerzita Pavla Jozefa Šafárika v Košiciach, 2021.

Tolstoj, L. N. Anna Kareninová. Preklad N. Szabová. Bratislava: Slovart, 2019. 
Zatloukalová, A. Specifika seriálové adaptace (od počátků až po současnost). In: Fedrová, S., Jedličková, A. (eds.) Intermediálni poetika př́běhu. Praha: Akropolis, 2011, s. 210-227.

\section{Audiovizuálne zdroje}

Blair, D. Anna Kareninová (televízna miniséria). Vel'ká Británia: Company Television Production, 2000.

Coleman, B. Anna Kareninová (televízny seriál). Vel'ká Británia: BBC, 1977.

Klimenko, J. Anna Kareninová (televízna miniséria). Rusko: Ugra-Film Company, 2009.

Šachnazarov, K. Anna Kareninová (televízny seriál). Rusko: Mosfilm Company, 2017. 